\title{
VALUE-AT-RISK (VaR) FOR LQ - 45 COMPANIES
}

\author{
Rangga Handika ${ }^{1}$ \\ Macquarie University - Sydney Australia
}

\begin{abstract}
This paper offers a new measurement of risk, Value-at-Risk (VaR) for LQ-45 index in Indonesian Stock Exchange (ISX). Basic finance uses standard deviation in measuring and quantifying the risks. This paper uses $\mathrm{VaR}$ as a risk measure by using historical and analytical methods. This study uses the data containing all LQ-45 weekly data from January $1^{\text {st }}$, 2005 to December, $31^{\text {st }}$ 2010. Moreover, this paper also calculates VaR of three indices (IHSG, Dow Jones, and S\&P 500) for benchmarking purpose. This study finds that LQ-45 companies have VaR ranging from 5.30 to -41.05 percent with 95 percent level of confidence. It means that we can expect to suffer a minimum weekly loss between 5.30 to 41.05 percent in 5 percent probability when we invest in the LQ-45 companies stocks individually. Furthermore, this study finds that individual LQ-45 stock is riskier than indices based on VaR measure. This paper also concludes that individual LQ-45 stock tends not to follow normal distribution while index tends to follow by comparing their historical and analytical VaR calculation.
\end{abstract}

Keywords: Value-at-Risk (VaR), Historical Method, Analytical Method, LQ-45 ${ }^{1}$ Rangga Handika is a $\mathrm{PhD}$ student in Financial Risk Management at Macquarie
University - Sydney Australia, rhandikapro@yahoo.com 


\section{INTRODUCTION}

So far, most of the basic finance literatures use standard deviation to quantify the risks. Standard deviation reflects the distribution of the difference between the actual and expected return. It measures how far the actual return deviates from the expected return. The standard deviation is the basic of quantifying risk so that some finance textbooks always cover in a risk and return chapter (Keown et al., 2004; Ross et al., 2005; and Jones, 2007) as an essential financial instrument indicator.

Standard deviation can answer the limitation of expected return indicator which only answers the return of a certain financial instrument without considering its risks. Indeed, such risk factor is essential in the investment decision because different investors have different risks tolerance. Ignoring risk factor in a financial instrument, an investor can mistakenly make an investment decision. For instance, financial instrument A provides 8 percent expected return and financial instrument B provides 10 percent expected return. If we ignore the risk factor, we will blatantly choose financial instrument $\mathrm{B}$ because it provides higher expected return. However, if later we get the information that instrument B has 5 times higher risk factor than $\mathrm{A}$, we will change our decision since instrument $\mathrm{B}$ provides only 1.25 times expected return than A but has 5 times higher risk factor than A. Thus, the excess of the expected return does not commensurate enough the excess of the risk. Actually, an appropriate investment objective should carefully consider it risk. Here we can see that standard deviation can tackle the limitation of expected return indicator.

Nevertheless, the risk measurement using standard deviation is not sufficient because standard deviation cannot answer certain problems faced by the investors. One of the problems is the investor' question about: "When I (an investor) would like to invest in a financial instrument, how much the minimum loss that I will suffer in a period so that I can prepare sufficient capital or reserve for my investments?'. Standard deviation clearly cannot answer to this question. Indeed, the question often arises when investors decide to invest in certain financial instruments.

Therefore, Value-at-Risk (VaR) emerges to respond the question. VaR provides answer about how much the minimum loss that an investor will 
suffer in certain period with certain level of confidence (Hull, 2007). By using certain quantitative methods, VaR presents to answer the question required to calculate capital or reserve required. VaR emerged from the practitioners in the early 1990 when the executives of JP Morgan, a world renowned investment banking, asked how much their exposure in the next 24 hours (Hull, 2007). The analysts replied to the question by adopting Markowitz model to calculate VaR. At that time, it was not an easy task since their VaR calculation required portfolio data around the world. Then, other banks followed this calculation model and thus, VaR is considered as one of important risk measurement. JP Morgan develops comprehensively the VaR model by launching "RiskMetrics" in 1994.

Nowadays, VaR has become an international standard to measure risk of the financial instrument. There are also some VaR extensions such as: Cash-flow-at-Risk (CaR) and Conditional-autoregressive-Value-at-Risk (CaViaR) which are the derivation of the basic VaR (Stulz, 2003). Moreover, some researches in the world have been done to the advanced level such as So and Yu (2006) who developed seven models Generalized Autoregressive Conditional Heteroscedasticity (GARCH) in estimating VaR value. Another research work is done by Adesi et al. (2002) who introduced Filtered Historical Simulation (FHS) to improve basic VaR methodology.

This paper presents the basic methodology and analysis VaR that are implemented in LQ-45 companies in the Indonesian Stock Exchange. The author tries to analyze empirically using Indonesia stock data to map stocks risk in Indonesia with LQ-45 as the proxy. This paper uses both VaR calculation methods: 1. Historical Method and 2. Analytical Method. For the analytical method, the author uses two different standard distribution assumptions: normal distribution and t-student distribution.

The author hope that the readers will get enlightenment about how much minimum losses (with certain probability and confidence level) when investing in the Indonesia stock market. Using proper investment risk analysis, investors can choose to invest in LQ-45 stock companies that suit their risk tolerance.

The remaining of this paper is organized as follows: 2. Literature Review and Hypothesis Development containing VaR and research questions, 3. 
Research Methodology that explains VaR calculation methodology, 4. Results that shows and analyzes the research results, 5. Conclusion containing major summary of this research, the research implication and limitations, 6. References.

\section{LITERATURE REVIEW AND HYPOTHESIS DEVELOPMENT}

$\mathrm{VaR}$ is the risk measurement indicator that calculates how much minimum losses can occur in certain period with the certain confidence interval. That is the common definition about $\mathrm{VaR}$ in some finance literatures (Jorion, 2007; Stulz, 2003; Hull, 2007). There are some bit variations in how they develop the extension from the basic VaR. Therefore, we can conclude that VaR provides information about:

- Minimum losses that can occur in certain period with the certain confidence interval (implies a probability level).

- Definition:

$$
\text { Probability (Amount losses } R p>V a R)=1 \text { - c }
$$

whereas $\mathrm{c}=$ confidence interval

- Example:

1 Day 95 \% VaR Rp 1 Million, means that investor can expect to suffer losses, at least, Rp 1 Million in one day with the 5 percent probability of occurrence.

1 Week $99 \%$ VaR $3 \%$, means that investor can expect to suffer losses, at least, $3 \%$ of capital in one week with the 1 percent probability of occurrence. .

- Important notes:

We can see that VaR "merely" provides the information about minimum losses, not expected losses.

VaR also provides a horizon (period) that the losses occur and with its probability.

VaR does not answer about the maximum losses; (again) VaR "merely" "merely" provides the information about minimum losses.

The next question is how to calculate VaR? This paper explains 2 (two) methods (Stulz, 2003; Hull, 2007) that are widely used in the world: 1 . Historical Method and 2. Analytical Method. In short, historical method calculates VaR based on historical probability distribution of a financial 
instrument while analytical method calculates VaR based on standard assumed probability distribution. The most widely used standard assumption of probability distribution is a standard normal distribution.

Now we realize that how simple to calculate VaR is. The knowledge required to calculate $\mathrm{VaR}$ is only basic algebra and normal (and t-student) distributions statistics. This simplicity causes VaR is rapidly used in the financial institutions around the world. VaR is perceived to be a simple, concise and consistent indicator of the "reasonable losses" in financial instrument (Culp et al., 1998). Another implication is that companies can use VaR to determine appropriate level of capital (Jorion, 2007). On the other hand, we have to be carefully in using VaR since this simplicity is also dangerous. Krause (2003) argues that a serious potential misinterpretation can occur in using VaR concept. This can lead big problem when we use VaR without realizing its flaws.

Actually, VaR satisfies most of coherent risk measurement. According to Artzner et al. (1999), a coherent risk measurement should possess four characteristics below: $=$

1. Positive Homogeneity; when a portfolio XYZ size is change to be $\Omega$ times (and citeris paribus), the new portfolio must possess $\Omega$ times the original risks.

2. Translation Invariance; when we add certain amount of cash $\mathrm{K}$ to a portfolio (and citeris paribus), the portfolio risk should be reduced as much as $\mathrm{K}$.

3. Monotonicity; when an instrument A has smaller return than other instrument (and citeris paribus), this implies that instrument $\mathrm{A}$ has higher risk measurement.

4. Sub-addivity, when both instruments are combined, the total risks must not exceed the sum of each instrument individually before the combination.

Hull (2007) analyzes and concludes that VaR satisfies all of the coherent characteristics, unless Sub-addivity. This is one of the VaR drawbacks.

Other VaR drawbacks, majorities are due to the simplification of VaR itself, are: 
1. Historical Method uses historical data to determine VaR. This implies that history will repeat itself. We realize that historical event is not necessarily a proper projection for the future.

2. Analytical Method uses a distribution assumption to determine VaR. In fact, the instrument distribution could significantly differ from the assumed distribution. Thus, VaR will be inaccurate.

3. The simplicity of VaR tempts us to ignore other important aspects of $\mathrm{VaR}$ such as VaR dynamic and integrated $\mathrm{VaR}$ in an institution with lots of different investments instruments. Berkowitz and O'brien (2002) find that an institution that poorly records the $\mathrm{VaR}$ is caused by ignoring VaR dynamic. They suggest a dynamic VaR method that will update the VaR periodically. Another study by Perignon et al. (2008) finds that companies are incorrect in calculating VaR because they are not able to properly measure an integrated market risks. This research implicitly suggests considering the correlation among different business units that face different market risks.

4. Krause (2003) uses Bienaynie-Chebyshev theorem to show that estimated $\mathrm{VaR}$ is significantly different from maximum VaR. This implies that VaR estimation is seriously misleading because the requirement capital is actually much higher. Krause (2003) also shows a potential bias in calculating $\mathrm{VaR}$ when we ignore the correlation among multiple investments instrument. The presence of the correlation causes multiplier effect simultaneously that has not been anticipated by basic VaR.

VaR is still useful, however. VaR can provide, at least, minimum losses that investors can suffer in an investment instrument. This is very useful in making investments decision since investors can choose proper instrument that suits their risk preference.

This paper presents VaR for LQ-45 stocks compared with indices (Jakarta Composite Stock Index - IHSG, Dow Jones USA and S\&P 500 USA). We will see that how the LQ-45 stocks risk indicator compared to those indices, equal, higher or lower. The VaR in this paper is limited to basic VaR by different methods. Ideally, VaR historical and analytical are not substantially different, otherwise, the assumption distribution is not appropriate anymore. Thus, investors cannot assume anything about future distribution by using standard statistic distribution assumptions. 
This table presents the hypothesis and implications in this paper:

\begin{tabular}{|l|l|l|}
\hline H0 A & $\begin{array}{l}|c| \\
\text { VaR LQ-45 is equal to VaR } \\
\text { indices }\end{array}$ & $\begin{array}{l}\text { LQ-45 has equal risks with the } \\
\text { indices. This means that LQ-45 } \\
\text { is representative enough to show } \\
\text { the indices' risks. }\end{array}$ \\
\hline H1 A & $\begin{array}{l}\text { VaR LQ-45 is not equal to } \\
\text { VaR indices }\end{array}$ & $\begin{array}{l}\text { LQ-45 has different risks with } \\
\text { the indices. This means that LQ- } \\
45 \text { is not representative to show } \\
\text { the indices' risks. }\end{array}$ \\
\hline H0 B & $\begin{array}{l}\text { Historical VaR is relatively } \\
\text { equal to Analytical VaR }\end{array}$ & $\begin{array}{l}\text { The return distribution of LQ-45 } \\
\text { follows certain } \\
\text { statistics distribution. }\end{array}$ \\
H1 B & $\begin{array}{l}\text { Historical VaR is not } \\
\text { relatively equal } \\
\text { Analytical VaR }\end{array}$ & $\begin{array}{l}\text { The return distribution of LQ-45 } \\
\text { does not follow certain standard } \\
\text { statistics distribution. }\end{array}$ \\
\hline
\end{tabular}

\section{RESEARCH METHODOLOGY}

This paper calculates VaR for LQ-45 company stocks using Historical and Analytical methods. For Analytical method, this paper uses normal distribution and t-student distribution. Next paragraphs explain the detail of the computation procedures.

Historical $\mathrm{VaR}$ is calculated through following stages:

1. Quoting time series (daily, weekly, monthly, or yearly) historical price of an investment instrument;

2. Ordering the data chronologically;

3. Calculate the return of the investment instrument for each period;

4. Ordering the return data (from number 3);

5. Determining the confidence interval (i.e. $95 \%, 97.5 \%$ or $99 \%$ );

6. Quoting the return in the rank order of the confidence interval. For instance: There are 100 time series data with $99 \%$ confidence level, thus we quote the return in the rank number $1((100) \times(100 \%-99 \%))$ from below. 
7. The value quoted in the step number 6 is the Historical VaR.

Historical VaR is calculated through following stages:

1. Quoting time series (daily, weekly, monthly, or yearly) historical price of an investment instrument;

2. Ordering the data chronologically;

3. Calculate the return of the investment instrument for each period;

4. Ordering the return data (from number 3 );

5. Determining the confidence interval (i.e. $95 \%, 97.5 \%$ or $99 \%$ );

6. Quote Z-value (in the normal distribution) and t-value (in the t-student distribution) based on the confidence interval;

7. Calculate Analytical VaR by formula $=$ mean $+($ standard deviation $x \mathrm{Z}$ (or t));

Data contains weekly LQ-45 companies' price and 3 indices (IHSG, Dow Jones and S7P 500) for the period from $1^{\text {st }}$ January 2005 to $31^{\text {st }}$ December 2010. The LQ-45 companies are companies that are classified as LQ-45 based on Indonesia Stock Exchange Announcement Number: Peng00023/BEI.PSH/01-2011 (BEI, 2011) dated on 31 January 2011. Table 1 presents the list of LQ-45 companies. Some of weekly data of certain companies are "not available" during that period. This is not a big problem since VaR methodology procedure will automatically based on available data. All indices have all price data during that period. 
Table 1. LQ-45 Companies as of $31^{\text {st }}$ January 2011

\begin{tabular}{|c|c|l|c|c|l|}
\hline No & Code & \multicolumn{1}{|c|}{ Company Name } & No & Code & \multicolumn{1}{|c|}{ Company Name } \\
\hline 1 & AALI & Astra Agro Lestari & 24 & GGRM & Gudang Garam \\
\hline 2 & ADRO & Adaro Energy & 25 & GJTL & Gajah Tunggal \\
\hline 3 & ANTM & Aneka Tambang (Persero) & 26 & INCO & International Nickel Indonesia \\
\hline 4 & ASII & Astra International & 27 & INDF & Indofood Sukses Makmur \\
\hline 5 & ASRI & Alam Sutera Realty & 28 & INDY & Indika Energy \\
\hline 6 & BBCA & Bank Central Asia & 29 & INTP & Indocement Tunggal Prakasa \\
\hline 7 & BBKP & Bank Bukopin & 30 & ISAT & indosat \\
\hline 8 & BBNI & Bank Negara Indonesia (Persero) & 31 & ITMG & Indo Tambangraya Megah \\
\hline 9 & BBRI & Bank Rakyat Indonesia (Persero) & 32 & JSMR & Jasa Marga (Persero) \\
\hline 10 & BBTN & Bank Tabungan Negara (Persero) & 33 & KLBF & Kalbe Farma \\
\hline 11 & BDMN & Bank Danamon Indonesia & 34 & LPKR & Lippo Karawaci \\
\hline 12 & BJBR & Bank Pembangunan Daerah Jawa Barat dan Banten & 35 & LSIP & PP London Sumatra Indonesia \\
\hline 13 & BMRI & Bank Mandiri (Persero) & 36 & MEDC & Medco Energi International \\
\hline 14 & BNBR & Bakrie \& Brothers & 37 & PGAS & Perusahaan Gas Negara (Persero) \\
\hline 15 & BRAU & Berau Coal Energy & 38 & PTBA & Tambang Batubara Bukit Asam (Persero) \\
\hline 16 & BSDE & Bumi Serpong Damai & 39 & SMCB & Holcim Indonesia \\
\hline 17 & BTEL & Bakrie Telecom & 40 & SMGR & Semen Gresik (Persero) \\
\hline 18 & BUMI & Bumi Resources & 41 & TINS & Timah (Persero) \\
\hline 19 & CPIN & Charoen Pokphand Indonesia & 42 & TLKM & Telekomunikasi Indonesia (Persero) \\
\hline 20 & DOID & Delta Dunia Makmur & 43 & UNSP & Bakrie Sumatera Plantation \\
\hline 21 & ELSA & Elnusa & 44 & UNTR & United Tractors \\
\hline 22 & ELTY & Bakrieland Development & 45 & UNVR & Unilever Indonesia \\
\hline 23 & ENRG & Energi Mega Persada & & & \\
\hline
\end{tabular}

\section{RESULTS}

The first part of this section provides descriptive statistics while the second part provides VaR for LQ-45 companies and indices. Those two parts contain each analysis that hopefully will provide readers about the risks in Indonesian stock markets and how we should analyze two different VaR methods.

Table 2 shows the descriptive statistics (mean, median and standard deviation) of the return of the LQ-45 companies and indices. We can see that the mean companies returns are from -1.17 percent to 1.76 percent (with mean 0.49 percent and standard deviation 0.53 percent) meanwhile indices returns are from 0.02 percent to 0.41 percent. Furthermore, the companies median returns are from -1.00 percent to 1.14 percent (with mean 0.28 percent and standard deviation 0.45 percent) meanwhile indices 
returns are from 0.17 percent to 0.91 percent. The companies volatilities (standard deviations) are from 3.61 percent to 24.17 percent with mean 8.50 percent and standard deviation 4.01 percent) meanwhile indices volatilities are from 2.80 percent to 3.75 percent.

At a glance we can see that the companies' returns tend to have more variations than indices. This is consistent with the portfolio diversification theory stating that indices contain only systematic risk since nonsystematic risks have been eliminated.

Table 3 presents the results of Historical and Analytical VaR calculations for LQ-45 companies and indices. For Analytical VaR, the results between normal and t-student distribution assumptions do not differ significantly because in large sample (313 weekly return data), t-student distribution will be closely to normal distribution. This paper uses 95 percent confidence interval.

We can see that Historical VaR for companies range from -20.66 percent to -5.72 percent (with mean -10.53 percent and standard deviation 3.27 percent) while Historical VaR for indices range from -5.89 percent to 4.63 percent. Then, Analytical VaR - normal distribution assumption - for companies range from -40.93 percent to -5.30 percent (with mean -13.49 percent and standard deviation 6.63 percent) while Analytical VaR normal distribution assumption - for indices range from -5.76 percent to 4.54 percent. Analytical VaR - t-student distribution assumption - for companies range from -41.05 percent to -5.64 percent (with mean -13.56 percent and standard deviation 6.63 percent) while Analytical VaR normal distribution assumption - for indices range from -5.78 percent to 4.56 percent. Analytical VaR using t-student distribution assumption is not different from Analytical $\mathrm{VaR}$ using normal distribution assumption because of the large sample. 
Table 2.

Means, Medians and Volatilities Return LQ-45 Companies and Indices

\begin{tabular}{|c|c|c|c|c|c|}
\hline \multicolumn{6}{|c|}{ Companies and Indices } \\
\hline 'AALI' & 'ADRO' & 'ANTM' & 'ASII' & 'ASRI' & 'BBCA' \\
\hline 'BBKP' & 'BBNI' & 'BBRI' & 'BBTN' & 'BDMN' & 'BJBR' \\
\hline 'BMRI' & 'BNBR' & 'BRAU' & 'BSDE' & 'BTEL' & 'BUMI' \\
\hline 'CPIN' & 'DOID' & 'ELSA' & 'ELTY' & 'ENRG' & 'GGRM' \\
\hline 'GJTL' & 'INCO' & 'INDF' & 'INDY' & 'INTP' & 'ISAT' \\
\hline 'ITMG' & 'JSMR' & 'KLBF' & 'LPKR' & 'LSIP' & 'MEDC' \\
\hline 'PGAS' & 'PTBA' & 'SMCB' & 'SMGR' & 'TINS' & 'TLKM' \\
\hline 'UNSP' & 'UNTR' & 'UNVR' & 'IHSG' & 'DOW JONES' & 'S\&P500' \\
\hline \multicolumn{6}{|c|}{ Means of the Weekly Returns } \\
\hline 0.76 & 0.37 & 0.04 & 0.63 & 0.26 & 0.56 \\
\hline 0.43 & 0.34 & 0.58 & 1.28 & 0.18 & 1.08 \\
\hline 0.45 & -1.17 & 0.63 & 0.37 & 0.17 & 0.44 \\
\hline 1.55 & 1.09 & -0.25 & -0.19 & -0.57 & 0.38 \\
\hline 0.42 & 1.26 & 0.61 & 0.29 & 0.54 & -0.01 \\
\hline 0.75 & 0.39 & 0.57 & 0.29 & 0.84 & 0.17 \\
\hline 1.42 & 0.92 & 0.41 & 0.44 & 1.76 & 0.21 \\
\hline $\mathbf{0 . 0 7}$ & 0.78 & 0.59 & 0.41 & 0.06 & 0.02 \\
\hline \multicolumn{6}{|c|}{ Medians of the Weekly Returns } \\
\hline 0.59 & $\mathbf{0 . 0 0}$ & 0.00 & 0.46 & $\mathbf{0 . 0 0}$ & 0.00 \\
\hline 0.00 & $\mathbf{0 . 0 0}$ & 0.82 & 0.54 & $\mathbf{0 . 0 0}$ & 0.96 \\
\hline 0.00 & 0.00 & 0.00 & 1.14 & 0.00 & 0.00 \\
\hline 0.80 & $\mathbf{0 . 0 0}$ & -0.51 & 0.00 & -1.00 & 0.00 \\
\hline 0.00 & 0.72 & 0.58 & 0.89 & 0.78 & 0.00 \\
\hline 0.97 & $\mathbf{0 . 0 0}$ & 0.00 & 0.00 & $\begin{array}{l}0.41 \\
\end{array}$ & 0.00 \\
\hline 0.62 & 0.63 & 0.00 & 0.60 & 0.91 & 0.00 \\
\hline 0.00 & 0.92 & 0.59 & 0.91 & 0.25 & 0.17 \\
\hline \multicolumn{6}{|c|}{ Volatilities (Standard Deviations) of the Weekly Returns } \\
\hline 7.67 & 8.30 & 8.57 & 6.53 & 7.77 & 4.83 \\
\hline 6.47 & 7.31 & 5.98 & 6.44 & 7.84 & 6.12 \\
\hline 6.21 & 24.17 & 3.61 & 12.75 & 8.56 & 10.02 \\
\hline 8.66 & 15.74 & 8.99 & 10.10 & 10.07 & 5.68 \\
\hline 7.43 & 13.24 & 6.48 & 9.69 & 6.46 & 6.25 \\
\hline 9.98 & 5.73 & 7.01 & 5.16 & 8.19 & 7.22 \\
\hline 11.33 & 7.58 & 7.53 & 7.21 & 22.31 & 4.36 \\
\hline 9.45 & 7.45 & 4.06 & 3.75 & 2.80 & 2.86 \\
\hline
\end{tabular}


Table 3

Historical VaR and Analytical VaR for LQ-45 Companies and Indices

\begin{tabular}{|c|c|c|c|c|c|}
\hline \multicolumn{6}{|c|}{ Companies and Indices } \\
\hline 'AALI' & 'ADRO' & 'ANTM' & 'ASII' & 'ASRI' & $\overline{\text { 'BBCA' }}$ \\
\hline 'BBKP' & 'BBNI' & 'BBRI' & 'BBTN' & 'BDMN' & 'BJBR' \\
\hline 'BMRI' & 'BNBR' & 'BRAU' & 'BSDE' & 'BTEL' & 'BUMI' \\
\hline 'CPIN' & 'DOID' & 'ELSA' & 'ELTY' & 'ENRG' & 'GGRM' \\
\hline 'GJTL' & 'INCO' & 'INDF' & 'INDY' & 'INTP' & 'ISAT' \\
\hline 'ITMG' & 'JSMR' & 'KLBF' & 'LPKR' & 'LSIP' & 'MEDC' \\
\hline 'PGAS' & 'PTBA' & 'SMCB' & 'SMGR' & 'TINS' & 'TLKM' \\
\hline 'UNSP' & 'UNTR' & 'UNVR' & 'IHSG' & 'DOW JONES' & 'S\&P500' \\
\hline \multicolumn{6}{|c|}{ Historical VaR } \\
\hline-10.78 & -9.79 & -15.11 & -8.97 & -10.32 & -7.82 \\
\hline-7.50 & -9.53 & -9.06 & -9.98 & -11.44 & -5.72 \\
\hline-9.12 & -16.03 & -6.82 & -20.66 & -10.18 & -14.66 \\
\hline-8.89 & -10.66 & -10.53 & -18.57 & -12.57 & -8.00 \\
\hline-11.98 & -12.65 & -9.53 & -14.42 & -9.80 & -8.79 \\
\hline-16.41 & -8.99 & -6.95 & -6.78 & -11.71 & -10.15 \\
\hline-8.65 & -8.84 & -10.70 & -8.34 & -11.20 & -6.19 \\
\hline-14.04 & -9.16 & -5.77 & -5.89 & -4.70 & -4.63 \\
\hline \multicolumn{6}{|c|}{ Analytical VaR - Normal Distribution } \\
\hline-11.85 & -13.29 & -14.06 & -10.11 & -12.52 & -7.39 \\
\hline-10.21 & -11.67 & -9.26 & -9.31 & -12.73 & -8.99 \\
\hline-9.77 & -40.93 & -5.30 & -20.61 & -13.91 & -16.04 \\
\hline-12.69 & -24.79 & -15.03 & -16.80 & -17.13 & -8.96 \\
\hline-11.81 & -20.52 & -10.05 & -15.65 & -10.10 & -10.30 \\
\hline-15.66 & -9.03 & -10.96 & -8.19 & -12.63 & -11.70 \\
\hline-17.21 & -11.55 & -11.97 & -11.43 & -34.94 & -6.96 \\
\hline-15.47 & -11.48 & -6.09 & -5.76 & -4.54 & -4.69 \\
\hline \multicolumn{6}{|c|}{$\frac{1}{1}$ Analytical VaR - t-Student Distribution } \\
\hline-11.89 & -13.39 & -14.14 & -10.15 & -12.60 & -7.41 \\
\hline-10.28 & -11.71 & -9.29 & -9.50 & -12.77 & -9.41 \\
\hline-9.80 & -41.05 & -5.64 & -20.76 & -13.96 & -16.10 \\
\hline-12.77 & -24.87 & -15.12 & -16.85 & -17.18 & -8.99 \\
\hline-11.84 & -20.58 & -10.08 & -15.76 & -10.13 & -10.33 \\
\hline-15.76 & -9.08 & -10.99 & -8.23 & -12.67 & -11.74 \\
\hline-17.26 & -11.59 & -12.01 & -11.49 & -35.05 & -6.98 \\
\hline-15.52 & -11.51 & -6.11 & -5.78 & -4.56 & -4.70 \\
\hline
\end{tabular}


From the results above, we can conclude that:

- Investing in LQ-45 companies has 5 percent probability to suffer losses at least 5.30 percent to 41.05 percent from weekly investments.

- Investing in IHSG, Dow Jones and S\&P 500 indices has 5 percent probability to suffer losses at least 5.54 percent to 5.89 percent from weekly investments.

- Both findings clearly show that VaR for LQ-45 companies are higher than indices VaR. This implies that investing in LQ-45 companies is more suitable for investors with higher risks tolerance [answering Hypothesis A]. For more conservative investors, they should invest in indices since the $\mathrm{VaR}$ (minimum losses) values are smaller.

- Historical VaR and Analytical VaR for LQ-45 companies differ significantly, about twice (for maximum range of VaR in LQ-45 companies). This implies that return distributions of LQ-45 tend not to follow certain statistics distribution [answering Hypothesis B].

- However, Historical VaR and Analytical VaR for LQ-45 tend to be relatively same. This implies that return distributions of LQ-45 tend to follow certain statistics distribution [answering Hypothesis B], in this case normal distribution.

\section{CONCLUSIONS}

This paper calculates Value-at-Risk (VaR) for LQ-45 companies in the Indonesian Stock Exchange (ISX) and IHSG, Dow Jones and S\&P 500 indices for benchmark. This paper uses historical and analytical methods for calculating VaR. For analytical method, this paper uses both normal and t-student distribution assumptions.

Even though $\mathrm{VaR}$ possesses some limitations, $\mathrm{VaR}$ is still beneficial. Krause (2003) argues that VaR is very useful to determine limit for investors, to facilitate capital allocation policy, and identify risks that needed to be anticipated. VaR is also easily understood for non-finance people. This is essential since how sophisticated a model is, if cannot be understood, the model inherits serious danger in decision making process. Therefore, Krause (2003) still suggests using VaR with a sound understanding of its limitations. 
This paper finds that VaR for LQ-45 companies range from - 5.30 percent to -41.05 percent and VaR for IHSG, Dow Jones, and S\&P 500 indices range from -4.54 percent to -5.89 percent. This means that weekly investments in LQ-45 companies have 5 percent probability to suffer losses, at least, 5.30 percent to 41.05 percent from the amount invested weekly. Meanwhile the weekly investments in IHSG, Dow Jones, and S\&P 500 indices have 5 percent probability to suffer losses, at least, 4.54 percent to 5.89 percent from the amount invested weekly. We can use those numbers for determining capital requirement when we want to invest in Indonesia Stock Market. The appropriateness of using VaR as capital requirement has been thoroughly analyzed by Cuocu and Liu (2006).

This paper finds that $\mathrm{VaR}$ in LQ-45 companies are higher than $\mathrm{VaR}$ in indices. This implies that LQ-45 companies have higher risks than indices. Moreover, this paper finds that Historical VaR and Analytical VaR differ for LQ-45 companies while are similar for indices. This implies that indices weekly returns distributions tend to follow normal distributions while LQ-45 companies weekly distributions do not.

This research is limited to basic VaR, which is static. The author realizes that there are some limitations in this paper. First, this paper does not answer which $\mathrm{VaR}$ is more reliable. We can perform back testing (as suggested by Hull, 2007; Jorion, 2007; Hull, 2009). Second, fundamental flaws in VaR can be rectified by dynamic model like GARCH-t (Chiu et al., 2006), extreme value theory for emerging market like Indonesia (Gencay and Selcuk, 2006), filtered historical simulation (FHS) method (Adesi et al., 2002), or other financial econometrics models like ARCH, GARCH, EMWA (Brooks, 2008; Hill et al., 2008). Third, we can extend by accommodating asymmetric respond in $\mathrm{VaR}$, i.e. positive return respond is different from negative return respond. According to Brooks and Perschand (2003) there are asymmetric conditional responds to the volatility in the Singapore and Thailand markets. We might use their method for Indonesia market. Fourth, VaR still cannot answer the expected losses. Fifth, this paper does not answer the correlation between return and VaR value. Sixth, investigating the correlation between companies $\mathrm{VaR}$ and cost of capital might be interesting because this will address the companies' risks exposure and their cost of capital. There 
some spaces for future research works and this paper presents the fundamental research of VaR in Indonesian Stock Market.

\section{REFERENCES}

Adesi, G. B., Giannopoulos, K., \& Vosper, L. (2002). Backtesting Derivative Portfolios with Filtered Historical Simulation (FHS)." European Financial Management, 8(1), 31 - 58.

Artzner, P., Delbaen, F., Eber, J.M., \& Heath, D. (1999). Coherent Measures of Risk. Mathematical Finance, 9(3), 203 - 228.

Berkowitz, J., \& O'Brien, J. (2002). How Accurate Are Value-at-Risk Models at Commercial Banks?. The Journal of Finance, LVII(3), $1093-1111$.

Brooks, C. (2008). Introductory Econometrics For Finance (2 ${ }^{\text {nd }}$ ed.). Cambridge UK: Cambridge University Press.

Brooks, C. \& Persand, G. (2003). The Effects of Asymetries on Stock Index Return Value-at-Risk Estimates. The Journal of Risk Finance, Winter, $29-42$.

Bursa Efek Indonesia. (2011). Pengumuman Saham Emiten Yang Masuk dan Keluar Dalam Penghitungan Indeks LQ-45 (No. Peng00023/BEI.PSH/01-2011). Jakarta: Bursa Efek Indonesia.

Chiu, C. L., Chiang, S. M., Hung, J. C., \& Chen, Y. L. (2006). Clearing Margin System in The Futures Markets-Applying The Value-atRisk Model to Taiwanese Data. Physica A, 367, 353 - 374.

Culp, C. L., Miller, M. H., \& Neves, A. M. P. (1998). Value at Risk: Uses and Abuses. Journal of Applied Corporate Finance, 10(4), 26 - 38.

Cuoco, D., \& Liu, H. (2006). An analysis of VaR-based capital requirements. Journal of Financial Intermediation, 15, 362 - 392 
Gencay, R., \& Selcuk, F. (2004). Extreme Value Theory and Value-AtRisk: Relative Performance in Emerging Markets. International Journal of Forecasting, 20, 287 - 303.

Hill, R. C., Griffiths, W. E., \& Lim, G. C. (2008). Principles Of Econometrics ( $3^{\text {rd }}$ ed.). New Jersey USA: John Wiley \& Sons Inc.

Hull, J. (2009). Options, Futures, and Other Derivatives ( $7^{\text {th }}$ ed.). New Jersey USA: Pearson Education Inc.

Hull, J. (2007). Risk Management and Financial Institutions. New Jersey USA: Pearson Education Inc.

Jones, C. P. (2007). Investments: Analysis and Management (10 ${ }^{\text {th }}$ ed.). USA: John Wiley and Sons.

Jorion, P. (2007). Value At Risk: The New Benchmark for Managing Financial Risk ( $3^{\text {rd }}$ ed.). USA: McGraw Hill.

Keown, A. J., Martin, J. H., Petty, J.W., \& Scott, D. F. (2004). Financial Management: Principles and Applications $\left(10^{\text {th }}\right.$ ed.). USA: Prentice Hall.

Krause, A. (2003). Exploring The Limitations of Value at Risk: How Good Is It in Practice?. The Journal of Risk Finance, Winter, 19 28.

Perignon C., Deng, Z. Y., \& Wang, Z. J. (2008). Do Banks Overstate their Value-at-Risk?. Journal of Banking and Finance, 32, 783 - 794.

Ross, S. A., Westerfield, R. W., \& Jaffe, J. F. (2005). Corporate Finance ( $7^{\text {th }}$ ed.). USA: McGraw-Hill International Edition.

So, M. K. P.., \& Yu, P. L. H. (2006). Empirical Analysis of GARCH Models in Value at Risk Estimation. Journal of International Financial Markets, Institutions and Money, 16, 180 - 197.

Stulz, R. M. (2003). Risk Management \& Derivatives. USA: Thompson South Western. 